See discussions, stats, and author profiles for this publication at: https://www.researchgate.net/publication/353082013

Impacts of land use and salinization on soil inorganic and organic carbon in the middle-lower Yellow River Delta

Article in Pedosphere · October 2021

DOl: 10.1016/\$1002-0160(21)60018-8

CITATIONS

0

8 authors, including:

Xiujun Wang

112 PUBLICATIONS 3,300 CITATIONS

SEE PROFILE

Some of the authors of this publication are also working on these related projects:

Carbon cycle in the Yellow River Basin View project

Project soil carbon cycle View project
Xinglan Li

Beijing Normal University

57 PUBLICATIONS 1,140 CITATIONS

SEE PROFILE 


\title{
Impacts of land use and salinization on soil inorganic and organic carbon in the middle-lower Yellow River Delta
}

\author{
Yang GUO ${ }^{1,4}$, Xiujun $\mathrm{WANG}^{1, *}$, Xianglan $\mathrm{LI}^{1, *}$, Minggang XU' ${ }^{2}$, Yuan $\mathrm{LI}^{3}$, Haonan $\mathrm{ZHENG}^{1}$, Yongming $\mathrm{LUO}^{3}$ \\ and Pete SMITH ${ }^{4}$ \\ ${ }^{1}$ College of Global Change and Earth System Science, Beijing Normal University, Beijing 100875 (China) \\ ${ }^{2}$ Institute of Agricultural Resources and Regional Planning, Chinese Academy of Agriculture Sciences, Beijing 100081 (China) \\ ${ }^{3}$ Key Laboratory of Coastal Zone Environmental Processes and Ecological Remediation, Yantai Institute of Coastal Zone Research, Chinese Academy of \\ Sciences, Yantai 264003 (China) \\ ${ }^{4}$ Institute of Biological and Environmental Sciences, University of Aberdeen, Aberdeen AB24 3UU (UK)
}

(Received November 13, 2019; revised December 17, 2019)

\begin{abstract}
Soil inorganic carbon (SIC) is an important reservoir of carbon (C) in arid, semi-arid, and semi-humid regions. However, knowledge is incomplete on the dynamics of SIC and its relationship with soil organic C (SOC) under different land use types in the semi-humid region, particularly in coastal zones impacted by soil salinization. We collected 170 soil samples from 34 profiles across various land use types (maize-wheat, cotton, paddy, and reed) in the middle-lower Yellow River Delta (YRD), China. We measured soil pH, electrical conductivity (EC), water-soluble salts, and SOC and SIC contents. Our results showed significant differences in both SOC and SIC among land use types. The dry cropland (maize-wheat and cotton) soils had significantly higher SOC and SIC densities (4.71 and $15.46 \mathrm{~kg} \mathrm{C} \mathrm{m}^{-2}$, respectively) than the paddy soils ( 3.28 and $14.09 \mathrm{~kg} \mathrm{C} \mathrm{m}^{-2}$, respectively) in the 0-100 cm layer. Compared with paddy soils, reed soils contained significantly higher SOC $\left(4.68 \mathrm{~kg} \mathrm{C} \mathrm{m}^{-2}\right)$ and similar SIC $\left(15.02 \mathrm{~kg} \mathrm{C} \mathrm{m}^{-2}\right)$ densities. There was a significant positive correlation between SOC and SIC densities over a $0-100 \mathrm{~cm}$ soil depth in dry cropland soils, but a negative relationship in the paddy soils. On average, SOC and SIC densities under maize-wheat cropping were $15 \%$ and $4 \%$ lower, respectively, in the salt-affected soils in the middle-lower YRD than the upper YRD. This study indicated that land use types had great influences on both SOC and SIC and their relationship, and salinization had adverse effect on soil C storage in the YRD. Key Words: C densities, C stocks, land use type, salt-affected soil, soil salinization
\end{abstract}

Citation: Guo Y, Wang X J, Li X L, Xu M G, Li Y, Zheng H N, Luo Y M, Smith P. 2021. Impacts of land use and salinization on soil inorganic and organic carbon in the middle-lower Yellow River Delta. Pedosphere. 31(6): 839-848.

\section{INTRODUCTION}

Soil carbon (C), soil organic C (SOC) and inorganic C (SIC), plays a significant role in the global $\mathrm{C}$ cycle and climate change (Eswaran et al., 1993; Lal, 2004). The global SOC pool was estimated to be $1220-1576 \mathrm{Pg}$ in the $0-100 \mathrm{~cm}$ layer (Batjes, 1996), which is about 2-3 times the $C$ pool in the biosphere (Rosenzweig and Hillel, 2000) and twice the $\mathrm{C}$ pool in the atmosphere (Schlesinger, 1999). At present, SOC has received a lot of attention, while fewer studies have focused on SIC. Although limited studies indicate that the global SIC pool is also large (i.e., 695-1 738 Pg over $0-100 \mathrm{~cm})$, there remains a large uncertainty in estimating the SIC pool (Eswaran et al., 2000).

A number of studies have shown that land use and management can have large impacts on SOC and SIC dynamics (Wu et al., 2003, 2009; Mikhailova and Post, 2006; Meng et al., 2014). For instance, land cover with different vegetation types can significantly affect SOC content because of the large differences in the root systems and associated changes in microbial processes and soil chemical and physical properties (Zhao et al., 2016; Han et al., 2018; Jobbágy and Jackson, 2000). Land management and agricultural practices (i.e., cultivation, fertilization, and irrigation) have great influences on SIC storage (Wang et al., 2014; Bughio et al., 2016). A few studies have shown that both SOC and SIC stocks are much larger in croplands than in the non-cropland of Northwest China (Su et al., 2010; Wang J P et al., 2015) and in the Kursk region of Russia (Mikhailova and Post, 2006).

Limited studies have focused on the SIC-SOC relationship and showed inconsistent findings among different land uses. Some studies have shown that there is a negative SICSOC relationship in various ecosystems, including cropland (Zeng et al., 2008), grassland, shrub land, and forest land (Zhao et al., 2016) in the Northwest China. However, other studies suggest that SIC density is positively correlated with SOC density in cropland (Su et al., 2010; Bughio et al., 
2016; Shi et al., 2017), forest (Gao et al., 2017), and desert (Zhang $\mathrm{N}$ et al., 2010) in North China. Further investigation is necessary to elucidate the relationship of SIC with SOC across different land use types.

Over the past decade, most studies focusing on the influence of land use on SIC dynamics and their relationship have been conducted in the arid and semi-arid areas of China (Chang et al., 2012; Tan et al., 2014; Wang et al., 2014; Zhang et al., 2015; Gao et al., 2017). There are few recent studies on the variations of both SIC and SOC in the semihumid cropland of North China (Bughio et al., 2016; Guo et al., 2016; Shi et al., 2017). These limited studies demonstrate that SOC and SIC in the semi-humid cropland are influenced by fertilization management (Bughio et al., 2016), and SIC has a positive relationship with $\mathrm{Ca}^{2+}$ and $\mathrm{Mg}^{2+}$ levels (Guo et al., 2016). In addition, our previous analyses indicate that there are significant differences in SOC and SIC densities between salt-affected soils and those containing less salts (Guo et al., 2016; Shi et al., 2017), implying that salinization might also impact soil $\mathrm{C}$ dynamics under other land use types in the semi-humid region.

The Yellow River Delta (YRD) is characterized by various degrees of salinization with about $60 \%$ of land covered by salt-affected soils (Fang et al., 2005; Cui et al., 2011; Li et al., 2014). Much of the land in the YRD has been exploited for use as cropland (i.e., cotton and paddy) from natural wetland (Zhao et al., 2018). Here, we hypothesize that land use types not only affect SOC and SIC densities but also their relationship in the YRD. The objectives of this study were to assess the impact of land use types on both SIC and SOC densities in salt-affected soils of semi-humid region and to evaluate the influences of salinization on SIC and SOC densities and stocks in the YRD.

\section{MATERIALS AND METHODS}

\section{Study region}

Our study area, covering the entire middle-lower YRD, is situated in the northeast of Shandong Province, China (Fig. 1). The area has a typical temperate continental monsoon climate with four distinct seasons. Annual mean temperature is $11.7-12.6^{\circ} \mathrm{C}$, and annual precipitation and evaporation are 530-630 $\mathrm{mm}$ and 1 900-2 $400 \mathrm{~mm}$, respectively. The land is flat, with low altitude $(<25 \mathrm{~m}$ above sea level) in most parts (Yu et al., 2014). The soils are classified as Alluvic Primosols, Marinic Aqui-Orthic Halosols, and Ochri-Aquic Cambosols (Cooperative Research Group on Chinese Soil Taxonomy, 2001). The alluvial soils were mainly developed on redeposited loess carried by the Yellow River from the Loess Plateau. Soil texture is similar across the study area, which on average contains $6.69 \% \pm 1.85 \%$ clay $(<0.002 \mathrm{~mm}), 33.3 \% \pm 13.7 \%$ silt $(0.002-0.02 \mathrm{~mm})$, and $59.7 \% \pm 13.3 \%$ sand $(0.02-2 \mathrm{~mm})$ (Li et al., 2016). The majority of land has been used for farming, and the rest is mainly wetland that is dominated by Suaeda (Suaeda salsa) and reed (Phragmites australis). The development of the cropping system is based on soil salinity, i.e., low salinity for wheat-maize and cotton and high salinity for paddy (Li et al., 2016). Thus, the main crop in the middlelower YRD is cotton and wheat-maize rotation, which has a rather longer cultivation history than paddy soils. For most of the paddies, farmers often use the freshwater from the Yellow River for salt-leaching in order to reduce soil salinity Mineral fertilizers are applied regularly in cropland soils (i.e., wheat-maize, cotton, and paddy soils), and straw is incorporated in most of the wheat-maize soils.

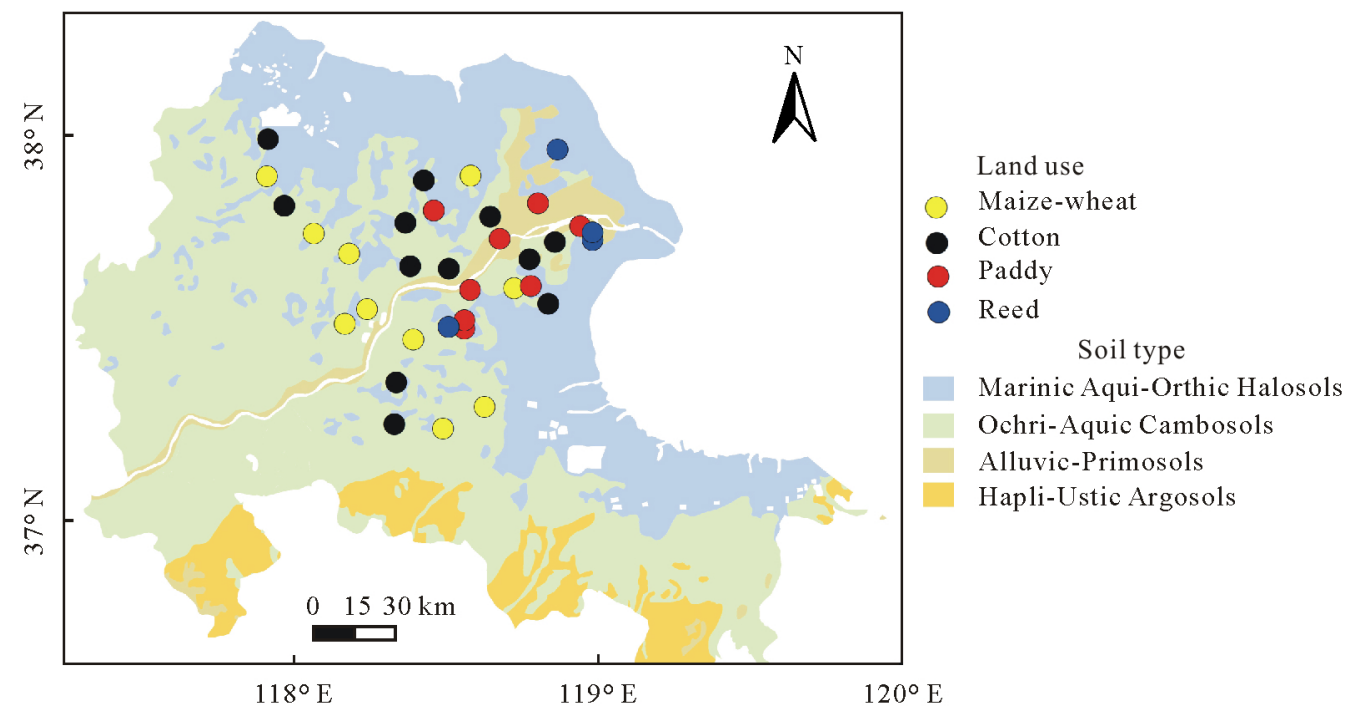

Fig. 1 Map of soil types and sampling sites under various land use types in the middle-lower Yellow River Delta, China. The map was generated using ArcMap 10.5 (http://www.esri.com/). 


\section{Soil sampling and analyses}

In order to study the influences of land use on the SOC and SIC distribution in the middle-lower YRD, we selected 34 soil sites across four types of vegetation in the fall of 2015 and 2016. The main cropping system in this study area is maize-wheat rotation, followed by cotton and then rice. Accordingly, we selected 10 maize-wheat rotation sites, 12 cotton sites, 8 paddy sites, and 4 reed sites (Fig. 1). For each site, 3-4 plots were randomly selected, and soil samples were collected from the 0-20, 20-40, 40-60, 60-80, and 80-100 cm layers (5 cm in diameter), mixed for the respective layers in the field, air dried, and passed through a 2-mm sieve. Soil bulk density (BD) was determined for a few representative profiles for each land use type (i.e., wheat-maize, cotton, paddy, and reed soils). Soil $\mathrm{pH}$ was measured at a soil:water ratio of 1:5 using a $\mathrm{pH}$ meter, electrical conductivity (EC) and total dissolved solids (TDS) using a conductivity meter (FiveEasy Benchtop FP30, Mettler Toledo, Zurich, Switzerland), and water-soluble $\mathrm{Ca}^{2+}, \mathrm{Mg}^{2+}$, and $\mathrm{Na}^{+}$using atomic absorption spectrometry by inductively coupled plasma mass spectrometry (ICPMS) (Agilent 7700x, Agilent, California, USA). Here, the changes in EC were used to infer variations in salinity (Zhang et al., 2011; Wang et al., 2017). Soil total C and SOC contents were analyzed using representative sub-samples $(<$ $0.25 \mathrm{~mm}$ ) with a CNHS-O analyzer (Model EuroEA3000, Arvato, Venice, Italy). For SOC measurement, soil samples were preprocessed with phosphoric acid $\left(\mathrm{H}_{3} \mathrm{PO}_{4}\right)$ to remove carbonate. The SIC content was obtained as the difference between soil total C and SOC contents. Detailed descriptions of methodology were given by Guo et al. (2016).

\section{Data analyses}

For each soil profile, densities of SOC, SIC, TDS, and water-soluble $\mathrm{Ca}^{2+} / \mathrm{Mg}^{2+}\left(X_{\text {DENSITY }}, \mathrm{kg} \mathrm{m}^{-2}\right)$ were calculated using their contents $\left(X_{i}, \mathrm{~g} \mathrm{~kg}^{-1}\right), \mathrm{BD}\left(E_{i}, \mathrm{~g} \mathrm{~cm}^{-3}\right)$ and thickness $\left(D_{i}, \mathrm{~cm}\right)$ for layer $i$ as follows:

$X_{\mathrm{DENSITY}}=\sum_{i=1}^{n} X_{i} \times D_{i} \times \frac{E_{i}}{100}$

For each vegetation type in this study, the stocks of SOC and SIC ( $Y_{\text {STOCK }}, \mathrm{kg}$ ) were then computed using the mean value of $X_{\text {DENSITY }}$ in the $0-100 \mathrm{~cm}$ soil layer and corresponding area $\left(\mathrm{m}^{2}\right)$ (Eq. 2):

$Y_{\mathrm{STOCK}}=X_{\text {DENSITY }} \times$ area

Areas of vegetation types were identified from the Shandong Statistical Yearbook-2016 (http://tjj.shandong.gov.cn/ tjnj/nj2016/indexch.htm), where the reed area was assumed to be the sizes of natural wetland, and the areas of other land use types were the sizes of corresponding land use types, taking the city areas (including Binzhou City and Dongying City, China) as the units of land use type areas (Sheng et al., 2016).

We used analysis of variance (ANOVA) and KruskalWallis tests for the data with normal and non-normal distribution, respectively, to assess the differences in soil properties among different vegetation types (i.e., maize-wheat, cotton, and paddy) and soil layers. The Duncan's post-hoc multiple comparisons (parametric test) or pairwise Wilcox test (nonparametric test) were used to compare the means at $P<$ 0.05 for dry land sites. Independent-sample $t$-test (parametric test) or Mann-Whitney test (non-parametric test) was used to compare soil properties between paddy and reed soils in the middle-lower YRD and also used to compare between middle-lower YRD and upper YRD. A $P$ value of $<0.05$ (two tail) was considered to be statistically significant. Pearson correlation and linear regression were performed using SPSS (version 24), and maps were created using SigmaPlot (version 12.5) and ArcMap (version 10.5).

\section{RESULTS}

\section{Soil chemical properties}

Mean soil $\mathrm{pH}$ in the $0-20 \mathrm{~cm}$ layer was significantly $(P<$ $0.05)$ lower in dry cropland soils (8.28 and 8.46 for maizewheat and cotton, respectively) than in paddy soils (8.63) (Table I). Soil pH was not significantly different between paddy soils and natural wetland soils (8.41). Similarly, soil pH was significantly higher in paddy soils (8.79-9.01) than in dry cropland soils (8.47-8.61 and 8.68-8.70 for maizewheat and cotton, respectively) below $20 \mathrm{~cm}$ and in natural wetland soils $(8.71)$ in the $80-100 \mathrm{~cm}$ soil layer $(P<0.05)$. In general, soil $\mathrm{pH}$ was significantly lower above $40 \mathrm{~cm}$ soil layers than below $40 \mathrm{~cm}$ soil layers of dry cropland soils (including maize-wheat and cotton) and paddy soils $(P<$ $0.05)$.

There were no obvious differences in mean values of soil EC, TDS, and water soluble $\mathrm{Ca}^{2+}$ and $\mathrm{Na}^{+}$contents in the 0-20 cm layer among the different land use types (Table I). Soil EC below $60 \mathrm{~cm}$ was significantly different $(P<0.05)$ among the different land use types, with the largest value in reed soils (479-705 $\left.\mu \mathrm{S} \mathrm{cm}^{-1}\right)$, followed by dry cropland soils (507-513 and $412-418 \mu \mathrm{S} \mathrm{cm}^{-1}$ for maize-wheat and cotton, respectively), and the smallest in paddy soils (265-290 $\mu \mathrm{S} \mathrm{cm}^{-1}$ ). The TDS was significantly higher in dry cropland soils (1 293-1 $308 \mathrm{mg} \mathrm{kg}^{-1}$ for cotton and $1046-1062 \mathrm{mg} \mathrm{kg}^{-1}$ for maize-wheat) and reed soils (1 221-1 $798 \mathrm{mg} \mathrm{kg}^{-1}$ ) than in paddy soils (668-733 mg $\left.\mathrm{kg}^{-1}\right)(P<0.05)$. Similarly, water-soluble $\mathrm{Ca}^{2+}$ content was also significantly higher in cotton $\left(108-118 \mathrm{mg} \mathrm{kg}^{-1}\right)$ 
TABLE I

Soil pH, electrical conductivity (EC), total dissolved solids (TDS), and water-soluble $\mathrm{Ca}^{2+}, \mathrm{Mg}^{2+}$ and $\mathrm{Na}^{+}$in the $0-20,20-40,40-60,60-80$ and 80-100 $\mathrm{cm}$ layers under different land use types in the middle-lower Yellow River Delta, China

\begin{tabular}{|c|c|c|c|c|c|c|c|}
\hline Soil depth & Land use type & $\mathrm{pH}$ & EC & TDS & $\mathrm{Ca}^{2+}$ & $\mathrm{Mg}^{2+}$ & $\mathrm{Na}^{+}$ \\
\hline $\mathrm{cm}$ & & & $\mu \mathrm{S} \mathrm{cm}^{-1}$ & & $\mathrm{mg}$ & & \\
\hline \multirow[t]{4}{*}{$0-20$} & Maize-wheat & $8.28 \pm 0.23^{\mathrm{a})} \mathrm{B}^{\mathrm{b})}$ & $520 \pm 434 \mathrm{~A}$ & $1325 \pm 1108 \mathrm{~A}$ & $131 \pm 60 \mathrm{~A}$ & $41 \pm 25 \mathrm{AB}$ & $471 \pm 431 \mathrm{~A}$ \\
\hline & Cotton & $8.46 \pm 0.23 \mathrm{AB}$ & $621 \pm 477 \mathrm{~A}$ & $1585 \pm 1216 \mathrm{~A}$ & $178 \pm 111 \mathrm{~A}$ & $62 \pm 36 \mathrm{~A}$ & $438 \pm 400 \mathrm{~A}$ \\
\hline & Paddy & $8.63 \pm 0.17 \mathrm{Aa}^{\mathrm{c})}$ & $298 \pm 92 \mathrm{Aa}$ & $753 \pm 238 \mathrm{Aa}$ & $99 \pm 17 \mathrm{Aa}$ & $26 \pm 13 \mathrm{Ba}$ & $171 \pm 107 \mathrm{Ab}$ \\
\hline & Reed & $8.41 \pm 0.29 \mathrm{a}$ & $1048 \pm 271 \mathrm{a}$ & $2671 \pm 689 a$ & $180 \pm 68 \mathrm{a}$ & $88 \pm 38 \mathrm{a}$ & $911 \pm 215 a$ \\
\hline \multirow[t]{4}{*}{$20-40$} & Maize-wheat & $8.47 \pm 0.21 \mathrm{~B}$ & $369 \pm 240 \mathrm{~A}$ & $938 \pm 614 \mathrm{~A}$ & $99 \pm 30 \mathrm{AB}$ & $36 \pm 19 \mathrm{~A}$ & $496 \pm 385 \mathrm{~A}$ \\
\hline & Cotton & $8.70 \pm 0.30 \mathrm{~A}$ & $497 \pm 268 \mathrm{~A}$ & $1266 \pm 683 \mathrm{~A}$ & $121 \pm 53 \mathrm{~A}$ & $46 \pm 20 \mathrm{~A}$ & $377 \pm 227 \mathrm{~A}$ \\
\hline & Paddy & $8.79 \pm 0.15 \mathrm{Aa}$ & $324 \pm 180 \mathrm{Ab}$ & $817 \pm 455 \mathrm{Ab}$ & $79 \pm 12 \mathrm{Ba}$ & $33 \pm 9 \mathrm{Aa}$ & $231 \pm 162 \mathrm{Aa}$ \\
\hline & Reed & $8.59 \pm 0.26 \mathrm{a}$ & $883 \pm 310 \mathrm{a}$ & $2250 \pm 790 a$ & $102 \pm 29 \mathrm{a}$ & $52 \pm 22 \mathrm{a}$ & $887 \pm 343 a$ \\
\hline \multirow[t]{4}{*}{$40-60$} & Maize-wheat & $8.57 \pm 0.21 \mathrm{~B}$ & $459 \pm 290 \mathrm{~A}$ & $1166 \pm 742 \mathrm{~A}$ & $85 \pm 28 \mathrm{AB}$ & $37 \pm 19 \mathrm{~A}$ & $541 \pm 402 \mathrm{~A}$ \\
\hline & Cotton & $8.73 \pm 0.26 \mathrm{AB}$ & $530 \pm 250 \mathrm{~A}$ & $1352 \pm 637 \mathrm{~A}$ & $107 \pm 34 \mathrm{~A}$ & $52 \pm 40 \mathrm{~A}$ & $455 \pm 253 \mathrm{~A}$ \\
\hline & Paddy & $8.83 \pm 0.21 \mathrm{Aa}$ & $282 \pm 105 \mathrm{Aa}$ & $712 \pm 267 \mathrm{Aa}$ & $76 \pm 15 \mathrm{Ba}$ & $37 \pm 23 \mathrm{Aa}$ & $281 \pm 257 \mathrm{Aa}$ \\
\hline & Reed & $8.65 \pm 0.18 \mathrm{a}$ & $733 \pm 86 a$ & $1868 \pm 218 \mathrm{a}$ & $83 \pm 13 a$ & $37 \pm 10 \mathrm{a}$ & $727 \pm 96 a$ \\
\hline \multirow[t]{4}{*}{$60-80$} & Maize-wheat & $8.61 \pm 0.27 \mathrm{~A}$ & $418 \pm 178 \mathrm{AB}$ & $1062 \pm 454 \mathrm{AB}$ & $80 \pm 15 B$ & $33 \pm 16 \mathrm{~A}$ & $553 \pm 386 \mathrm{~A}$ \\
\hline & Cotton & $8.69 \pm 0.33 \mathrm{~A}$ & $513 \pm 148 \mathrm{~A}$ & $1308 \pm 378 \mathrm{~A}$ & $108 \pm 34 \mathrm{~A}$ & $52 \pm 25 \mathrm{~A}$ & $492 \pm 285 \mathrm{~A}$ \\
\hline & Paddy & $8.88 \pm 0.22 \mathrm{Aa}$ & $290 \pm 130 \mathrm{Bb}$ & $733 \pm 332 \mathrm{Bb}$ & $88 \pm 26 \mathrm{Ba}$ & $35 \pm 19 \mathrm{Aa}$ & $300 \pm 267 \mathrm{Ab}$ \\
\hline & Reed & $8.64 \pm 0.10 \mathrm{a}$ & $705 \pm 54 \mathrm{a}$ & $1798 \pm 138 \mathrm{a}$ & $82 \pm 6 a$ & $36 \pm 5 a$ & $683 \pm 92 \mathrm{a}$ \\
\hline \multirow[t]{4}{*}{$80-100$} & Maize-wheat & $8.58 \pm 0.29 \mathrm{~B}$ & $412 \pm 136 \mathrm{~A}$ & $1046 \pm 347 \mathrm{~A}$ & $82 \pm 18 B$ & $34 \pm 12 \mathrm{~A}$ & $619 \pm 408 \mathrm{~A}$ \\
\hline & Cotton & $8.68 \pm 0.36 \mathrm{~B}$ & $507 \pm 138 \mathrm{~A}$ & $1293 \pm 351 \mathrm{~A}$ & $118 \pm 37 \mathrm{~A}$ & $69 \pm 45 \mathrm{~A}$ & $517 \pm 316 \mathrm{~A}$ \\
\hline & Paddy & $9.01 \pm 0.20 \mathrm{Aa}$ & $265 \pm 90 \mathrm{Bb}$ & $668 \pm 229 \mathrm{Bb}$ & $81 \pm 25 \mathrm{Ba}$ & $33 \pm 18 \mathrm{Aa}$ & $305 \pm 269 \mathrm{Aa}$ \\
\hline & Reed & $8.71 \pm 0.06 b$ & $479 \pm 70 \mathrm{a}$ & $1221 \pm 179 a$ & $84 \pm 6 a$ & $30 \pm 2 \mathrm{a}$ & $405 \pm 69 \mathrm{a}$ \\
\hline
\end{tabular}

a) Means \pm standard errors ( $n=10$ for maize-wheat soils, 12 for cotton soils, 8 for paddy soils, and 4 for reed soils).

b) Means with the same uppercase letter(s) indicate no significant differences at $P<0.05$ among maize-wheat, cotton, and paddy soils for each property in each layer.

c) Means with the same lowercase letter indicate no significant differences at $P<0.05$ between paddy and reed soils for each property in each layer.

and reed $\left(84-82 \mathrm{mg} \mathrm{kg}^{-1}\right)$ soils than in paddy soils (81$\left.88 \mathrm{mg} \mathrm{kg}^{-1}\right)(P<0.05)$. Overall, the mean values of soil EC, TDS, and water soluble $\mathrm{Ca}^{2+}$ and $\mathrm{Na}^{+}$contents for each land use type were not significantly different among different soil layers.

\section{Spatial distributions of SOC and SIC densities}

Our data revealed small spatial variability in both SOC and SIC densities in the 0-20 cm layer (Fig. 2a, b), showing a range of $0.99-2.65$ and $2.04-4.30 \mathrm{~kg} \mathrm{C} \mathrm{m}^{-2}$, respectively. Overall, SOC density was higher in the west of the middlelower YRD which was far away from the coastal zone, while relatively higher SIC density was found in the east section close to the coastal zone.

There were small spatial variations in both SOC and SIC densities in the 20-40 cm layer as well (Fig. 2c, d), with a range of $0.40-1.26$ and $2.35-4.93 \mathrm{~kg} \mathrm{C} \mathrm{m}^{-2}$, respectively. However, there were large spatial variations in both SOC and SIC densities in the 40-100 cm layer (Fig. 2e, f), showing a range of $1.02-2.89$ and $6.17-12.7 \mathrm{~kg} \mathrm{C} \mathrm{m}^{-2}$, respectively. The spatial distribution was similar between SOC and SIC densities in the 20-40 and 40-100 cm layers (i.e., higher densities of SOC and SIC in the west). Besides, both SOC and SIC densities in the 20-40 and 40-100 cm layers revealed a decreasing trend from inland to estuary areas.

\section{Contents of SOC and SIC under different land use types}

The SOC content decreased significantly with soil depth under all land use types (Fig. 3). Overall, SOC content decreased significantly from the $0-20 \mathrm{~cm}$ layer to the 20 $40 \mathrm{~cm}$ layer. Mean values of SOC content varied greatly in the profiles of dry cropland soils (i.e., from 6.23-8.16 to 2.10-2.11 $\mathrm{g} \mathrm{kg}^{-1}$ ) and reed soils (i.e., from 7.56 to $2.56 \mathrm{~g}$ $\mathrm{kg}^{-1}$ ), with less SOC content in the profiles of paddy soils (from 4.87 to $1.68 \mathrm{~g} \mathrm{~kg}^{-1}$ ). We averaged SOC densities in the $0-20$ and $20-100 \mathrm{~cm}$ layers for each land use type (Table II). Mean SOC density in the $0-20 \mathrm{~cm}$ layer was significantly $(P<0.05)$ lower in paddy soils $(1.26 \mathrm{~kg} \mathrm{C}$ $\mathrm{m}^{-2}$ ) than in dry cropland soils (1.69 and $2.02 \mathrm{~kg} \mathrm{C} \mathrm{m}^{-2}$ for maize-wheat and cotton, respectively) and natural wetland soils $\left(1.81 \mathrm{~kg} \mathrm{C} \mathrm{m}^{-2}\right)$. The SOC density in the $20-100 \mathrm{~cm}$ layer was significantly lower $(P<0.05)$ in paddy soils $\left(2.03 \mathrm{~kg} \mathrm{C} \mathrm{m}^{-2}\right)$ than in dry cropland soils $(2.75$ and $2.95 \mathrm{~kg}$ $\mathrm{C} \mathrm{m}^{-2}$ in maize-wheat and cotton, respectively).

The SIC content showed different vertical trends across land use types (Fig. 3). There was little vertical variation in SIC content under all land use types, i.e., 11.39-12.56, $10.46-10.55,10.33-10.34$, and $10.55-12.82 \mathrm{~g} \mathrm{~kg}^{-1}$ in maize-wheat, cotton, paddy, and reed soils, respectively. On average, SIC density in the $0-20 \mathrm{~cm}$ layer was not significantly different among paddy soils $\left(2.70 \mathrm{~kg} \mathrm{C} \mathrm{m}^{-2}\right)$, maize-wheat and cotton soils (2.84-3.11 kg C.m $\left.{ }^{-2}\right)$, and reed soils ( $3.08 \mathrm{~kg} \mathrm{C} \mathrm{m}^{-2}$ ) (Table II). There were significant 

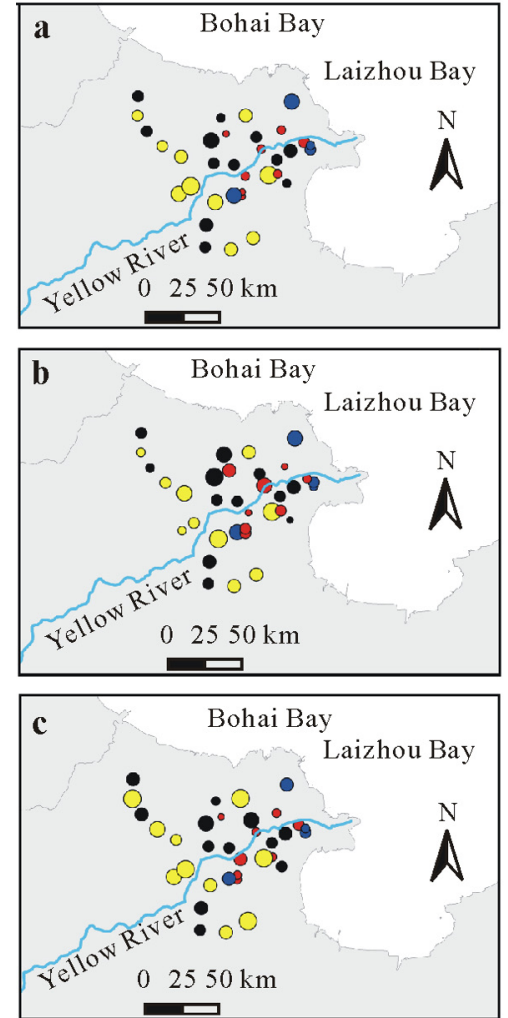

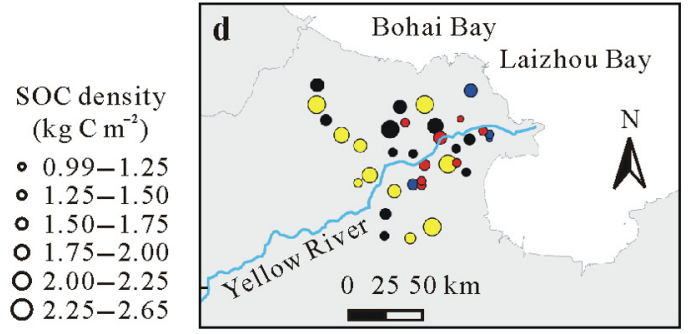

SIC density

$\left(\mathrm{kg} \mathrm{C} \mathrm{m}^{-2}\right)$

- 2.35-2.60

- $2.60-2.90$

$2.90-3.20$

- $3.20-3.50$

O $3.50-3.80$

$3.80-4.93$
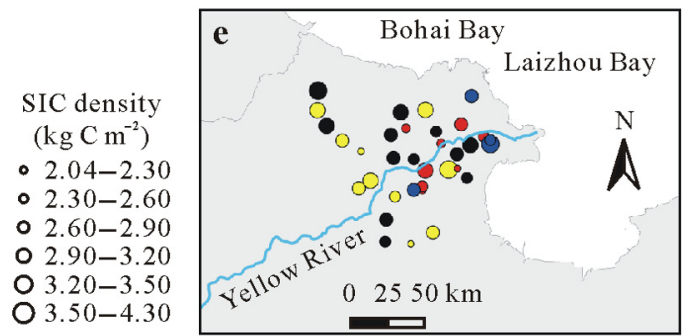

SOC density

$\left.(\mathrm{kg} \mathrm{C} \mathrm{m})^{-2}\right)$

- $1.02-1.20$

- $1.20-1.40$

- $1.40-1.80$

o $1.80-2.20$

O $2.20-2.60$

O $2.60-2.89$

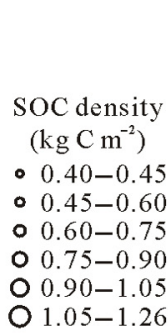

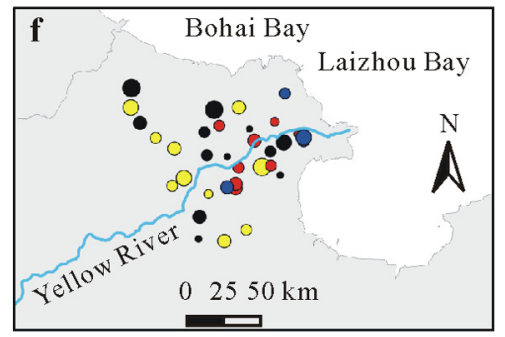

SIC density $\left.(\mathrm{kg} \mathrm{C} \mathrm{m})^{-2}\right)$

- 6.17-7.00

- $7.00-8.00$

- 8.00-9.00

9 $9.00-10.0$

O $10.0-11.0$

O $11.0-12.7$

Fig. 2 Spatial distribution maps of soil organic C (SOC) (a, c, and e) and inorganic C (SIC) (b, d, and f) densities in the 0-20 (a and b), 20-40 (c and d) and 40-100 cm (e and f) layers under four land use types of maize-wheat (yellow circles), cotton (black circles), paddy (red circles), and reed (blue circles) in the middle-lower Yellow River Delta, China. The maps were generated using ArcMap 10.5 (http://www.esri.com/).

\section{Content $\left(\mathrm{g} \mathrm{C} \mathrm{kg}^{-1}\right)$}

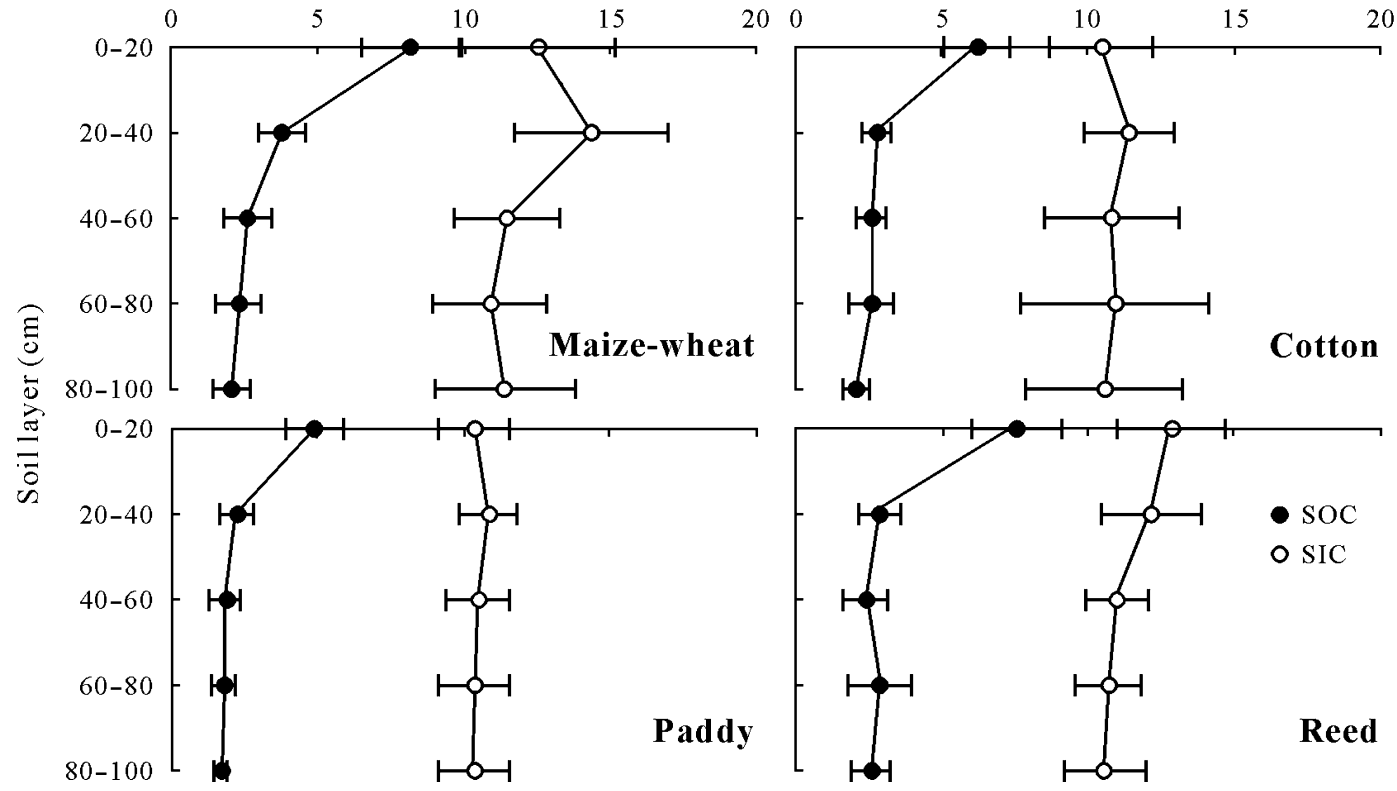

Fig. 3 Vertical distributions maps of soil organic C (SOC) and inorganic C (SIC) contents in the 0-20, 20-40, 40-60, 60-80, and 80-100 cm layers under four land use types of maize-wheat $(n=10)$, cotton $(n=12)$, paddy $(n=8)$, and reed $(n=4)$ in the middle-lower Yellow River Delta, China. Vertical bars indicate standard errors of the means.

differences in SIC density in the $20-100 \mathrm{~cm}$ layer in cropland soils $(P<0.05)$, with the largest value in maize-wheat soils $\left(13.39 \mathrm{~kg} \mathrm{C} \mathrm{m}^{-2}\right)$, followed by cotton soils $\left(11.84 \mathrm{~kg} \mathrm{C} \mathrm{m}^{-2}\right)$, and the smallest value in paddy soils $\left(11.39 \mathrm{~kg} \mathrm{C} \mathrm{m}^{-2}\right)$. No significant difference in SIC density in the $20-100 \mathrm{~cm}$ layer was found between paddy and reed soils. 
Relationships between SOC and SIC under different land use types

There were similar spatial distributions between SIC and SOC stocks, especially in the $20-40$ and $40-100 \mathrm{~cm}$ soil layers (Fig. 2). Our analyses showed that in dry cropland soils (including maize-wheat and cotton), SIC density had a significant positive correlation with SOC density in both the 0-20 and $0-100 \mathrm{~cm}$ soil layers $(P<0.001)$ (Fig. 4), with a greater slope of 2.3 in the $0-100 \mathrm{~cm}$ layer than in the $0-20 \mathrm{~cm}$ layer. Despite of the overall positive SIC-SOC relationship in the middle-lower YRD, higher SIC levels corresponded to lower SOC densities in paddy and reed soils, particularly in the $0-100 \mathrm{~cm}$ soil layer.

\section{DISCUSSION}

\section{Influences of land use and salinization on SOC}

Mean SOC density of dry croplands soils in our study (4.71 $\mathrm{kg} \mathrm{C} \mathrm{m}^{-2}$ ) is similar to the previously reported value $\left(5.01 \mathrm{~kg} \mathrm{C} \mathrm{m}^{-2}\right)$ in dry cropland soils of the lower YRD $(\mathrm{Li}$ et al., 2014), but lower than that $\left(5.73 \mathrm{~kg} \mathrm{C} \mathrm{m}^{-2}\right)$ in the upper YRD (Guo et al., 2016). The lower SOC density may be attributable to the shorter cultivation history in the middlelower YRD. In addition, our analyses also demonstrated that
SOC stock had a significantly negative relationship with mean values of soil $\mathrm{pH}$ and EC in the 0-20 and 0-100 cm soil layers in the dry cropland soils in the middle-lower YRD (Table III), indicating that the relatively low SOC density in the middle-lower YRD may be partly caused by soil salinization that can lead to poor growth thus less inputs of organic C into soil profile (Li et al., 2014; Yu et al., 2016). Zhao et al. (2017) also showed that lower levels of SOC are associated with higher soil salinity in the YRD. Furthermore, we compared $\mathrm{pH}$ and $\mathrm{EC}$ (representing salinization level) of dry cropland soils (maize-wheat and cotton soils) from this study with those of maize-wheat cropland soils from Guo Y et al. (2016) (Table IV). Mean values of soil $\mathrm{pH}$ and EC for each soil layer were significantly higher in the middle-lower YRD than in the upper YRD above $100 \mathrm{~cm}$ Clearly, the mean value of SOC content was lower in the middle-lower YRD (with higher salinization) than in the upper YRD (with lower salinization), indicating that soil salinization has adverse effects on SOC density in the YRD.

Land use types can have a great influence on SOC dynamics (Meng et al., 2014; Yu et al., 2016). Previous studies have shown that SOC density is greater in cropland than in non-cropland of northwestern China, which primarily results from fertilization and irrigation (Su et al., 2010; Wang

TABLE I

Soil organic C (SOC) and inorganic C (SIC) densities in the 0-20 and 20-100 cm layers under four land use types of maize-wheat, cotton, paddy, and reed in the middle-lower Yellow River Delta, China

\begin{tabular}{|c|c|c|c|c|c|}
\hline \multirow[t]{2}{*}{ Land use type } & \multicolumn{2}{|l|}{ SOC density } & & \multicolumn{2}{|l|}{ SIC density } \\
\hline & $0-20 \mathrm{~cm}$ & $20-100 \mathrm{~cm}$ & & $0-20 \mathrm{~cm}$ & $20-100 \mathrm{~cm}$ \\
\hline & & & \multirow{5}{*}{$\mathrm{kgC} \mathrm{m}^{-2}$} & & \\
\hline Maize-wheat & $2.02 \pm 0.31^{\mathrm{a})} \mathrm{A}^{\mathrm{b})}$ & $2.95 \pm 0.69 \mathrm{~A}$ & & $3.11 \pm 0.54 \mathrm{~A}$ & $13.39 \pm 1.68 \mathrm{~A}$ \\
\hline Cotton & $1.69 \pm 0.77 \mathrm{~B}$ & $2.75 \pm 0.43 \mathrm{~A}$ & & $2.84 \pm 0.36 \mathrm{~A}$ & $11.84 \pm 2.16 \mathrm{AB}$ \\
\hline Paddy & $1.26 \pm 0.18 \mathrm{Cb}^{\mathrm{c})}$ & $2.03 \pm 0.40 \mathrm{Ba}$ & & $2.70 \pm 0.44 \mathrm{Ab}$ & $11.39 \pm 0.89 \mathrm{Ba}$ \\
\hline Reed & $1.81 \pm 0.37 \mathrm{a}$ & $2.86 \pm 0.47 \mathrm{a}$ & & $3.08 \pm 0.45 \mathrm{a}$ & $11.94 \pm 0.80 \mathrm{a}$ \\
\hline
\end{tabular}

a) Means \pm standard errors ( $n=10$ for maize-wheat soils, 12 for cotton soils, 8 for paddy soils, and 4 for reed soils).

b) Means with the same uppercase letter(s) indicate no significant differences at $P<0.05$ among maize-wheat, cotton and paddy soils for SOC or SIC in each layer.

c) Means with the same lowercase letter indicate no significant differences at $P<0.05$ between paddy and reed soils for SOC or SIC in each layer.
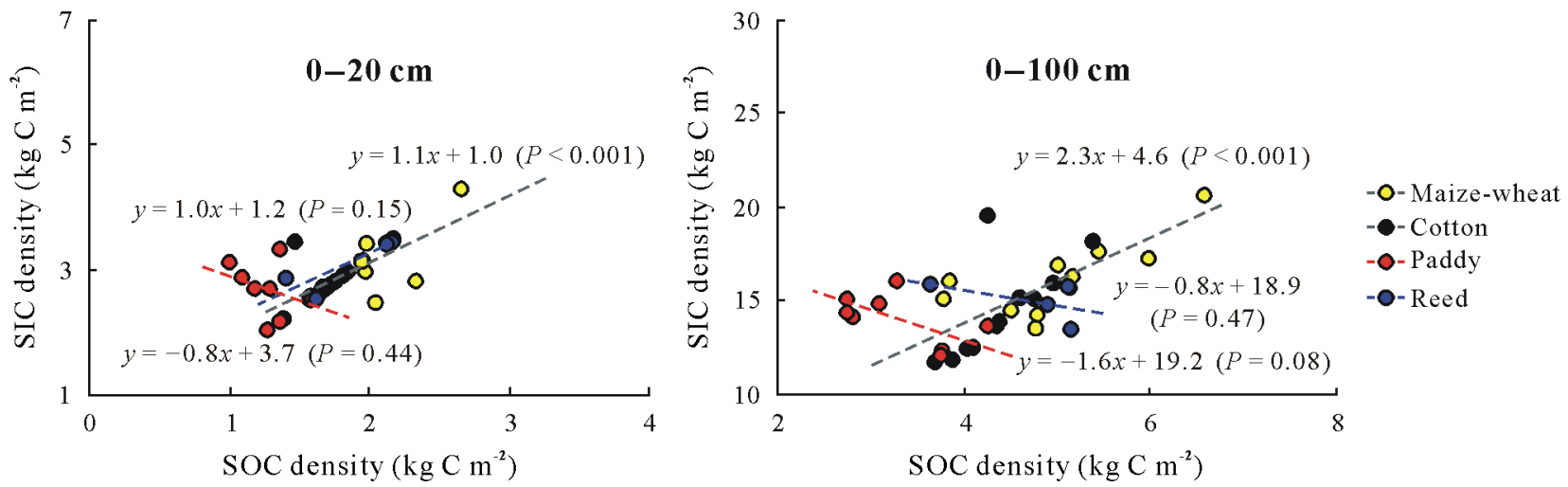

Fig. 4 Relationships between soil inorganic C (SIC) and organic C (SOC) densities in the 0-20 and 0-100 cm layers in dry cropland soils (maize-wheat and cotton), paddy soils, and reed soils in the middle-lower Yellow River Delta, China. 
TABLE III

Correlation coefficients between soil organic $\mathrm{C}$ (SOC) and inorganic $\mathrm{C}$ (SIC) densities and soil electrical conductivity (EC) and water soluble $\mathrm{Ca}^{2+}$ and $\mathrm{Mg}^{2+}$ in the 0-20 and 0-100 cm layers in dry cropland soils (maize-wheat and cotton) and paddy soils in the middle-lower Yellow River Delta, China

\begin{tabular}{lllllr}
\hline Soils & Layer & $\mathrm{pH}$ & $\mathrm{EC}$ & $\mathrm{Ca}^{2+}$ & $\mathrm{Mg}^{2+}$ \\
\hline \multirow{2}{*}{ Dry cropland } & $\mathrm{cm}$ & & & & \\
SOC density & $0-20$ & $-0.557^{*}$ & $-0.543^{*}$ & 0.072 & -0.367 \\
& $0-100$ & $-0.499^{*}$ & $-0.540^{*}$ & -0.229 & 0.108 \\
SIC density & $0-20$ & 0.380 & -0.306 & $0.550^{*}$ & -0.252 \\
& $0-100$ & 0.070 & $-0.560^{*}$ & 0.076 & 0.080 \\
Paddy & & & & & \\
SOC density & $0-20$ & -0.330 & -0.309 & 0.570 & -0.111 \\
& $0-100$ & 0.018 & -0.291 & 0.014 & -0.291 \\
SIC density & $0-20$ & 0.580 & -0.376 & $0.643^{*}$ & 0.00007 \\
& $0-100$ & 0.193 & -0.047 & -0.366 & -0.0666 \\
\hline
\end{tabular}

*Significant at the 0.05 probability level (2-tailed).

\section{TABLE IV}

Selected soil basic properties, soil organic C (SOC), inorganic C (SIC), pH, electrical conductivity (EC), and water soluble $\mathrm{Ca}^{2+}$ and $\mathrm{Mg}^{2+}$, in the $0-20,20-40,40-60,60-80$, and $80-100 \mathrm{~cm}$ in dry cropland in the middlelower (maize-wheat and cotton soils, $n=22$ ) and upper (maize-wheat soils, $n=31$ ) (Guo Y et al., 2016) Yellow River Delta (YRD), China

\begin{tabular}{|c|c|c|c|c|}
\hline \multirow[t]{3}{*}{ Layer } & \multicolumn{2}{|l|}{ SOC } & \multicolumn{2}{|l|}{ SIC } \\
\hline & Middle-lower & Upper & Middle-lower & Upper \\
\hline & YRD & YRD & YRD & YRD \\
\hline \multicolumn{5}{|c|}{$\mathrm{g} \mathrm{kg}^{-1}$} \\
\hline $0-20$ & 7.1Ba $\mathrm{B}^{\mathrm{a})}$ & $9.3 \mathrm{Aa}$ & 11.4Aab & $10.5 \mathrm{Ab}$ \\
\hline $20-40$ & $3.3 \mathrm{Bb}$ & $4.3 \mathrm{Ab}$ & $12.8 \mathrm{Aa}$ & 11.7Aab \\
\hline $40-60$ & $2.6 \mathrm{Bc}$ & $3.5 \mathrm{Ab}$ & $11.1 \mathrm{Ab}$ & 11.6Aab \\
\hline $60-80$ & $2.5 \mathrm{Ac}$ & 2.9Abc & $10.9 \mathrm{Bb}$ & $12.6 \mathrm{Aa}$ \\
\hline $80-100$ & 2.1Ac & $2.4 \mathrm{Ac}$ & $10.9 \mathrm{Bb}$ & $12.7 \mathrm{Aa}$ \\
\hline \multirow[t]{3}{*}{ Layer } & \multicolumn{2}{|l|}{$\mathrm{pH}$} & \multicolumn{2}{|l|}{$\mathrm{EC}$} \\
\hline & Middle-lower & Upper & Middle-lower & Upper \\
\hline & YRD & YRD & YRD & YRD \\
\hline \multicolumn{3}{|l|}{$\mathrm{cm}$} & \multicolumn{2}{|c|}{$\mu \mathrm{S} \mathrm{cm} \mathrm{cm}^{-1}$} \\
\hline $0-20$ & $8.4 \mathrm{Aa}$ & $8.1 \mathrm{Bb}$ & 576Aa & 239Bd \\
\hline $20-40$ & $8.6 \mathrm{Ab}$ & $8.3 \mathrm{Ba}$ & 495Aa & 264Bcd \\
\hline $40-60$ & $8.7 \mathrm{Ab}$ & 8.2Bab & $529 \mathrm{Aa}$ & $334 \mathrm{Bbc}$ \\
\hline $60-80$ & 8.7Ab & $8.2 \mathrm{Bb}$ & $565 \mathrm{Aa}$ & 409Bab \\
\hline $80-100$ & $8.6 \mathrm{Ab}$ & $8.2 \mathrm{Bb}$ & $606 \mathrm{Aa}$ & $444 \mathrm{Ba}$ \\
\hline \multirow[t]{3}{*}{ Layer } & \multicolumn{2}{|l|}{$\mathrm{Ca}^{2+}$} & \multicolumn{2}{|l|}{$\mathrm{Mg}^{2+}$} \\
\hline & Middle-lower & Upper & Middle-lower & Upper \\
\hline & YRD & YRD & YRD & YRD \\
\hline \multicolumn{3}{|l|}{$\mathrm{cm}$} & \multicolumn{2}{|c|}{$\mathrm{mg} \mathrm{kg}^{-1}$} \\
\hline $0-20$ & 157Aa & $90 \mathrm{Ba}$ & $52 \mathrm{Aa}$ & $26 \mathrm{Ba}$ \\
\hline $20-40$ & $111 \mathrm{Ab}$ & $85 \mathrm{Aa}$ & $41 \mathrm{Aa}$ & $27 \mathrm{Aa}$ \\
\hline $40-60$ & $97 \mathrm{Ab}$ & $85 \mathrm{Aa}$ & $45 \mathrm{Aa}$ & $28 \mathrm{Ba}$ \\
\hline $60-80$ & $95 \mathrm{Ab}$ & 89Aa & $43 \mathrm{Aa}$ & $29 \mathrm{Ba}$ \\
\hline $80-100$ & $102 \mathrm{Ab}$ & 91Aa & $53 \mathrm{Aa}$ & $31 \mathrm{Ba}$ \\
\hline
\end{tabular}

a) For a given soil layer, means with the same uppercase letter indicate no significant differences at $P<0.05$ between two regions; For a given region, means with the same lowercase letter(s) indicate no significant differences at $P<0.05$ among five soil layers for each property.

X J et al., 2015). Our study shows a significantly higher SOC density in dry cropland soils $\left(>4.44 \mathrm{~kg} \mathrm{C} \mathrm{m}^{-2}\right)$ than in paddy soils $\left(3.28 \mathrm{~kg} \mathrm{C} \mathrm{m}^{-2}\right)$ in the middle-lower YRD. The relatively higher level of SOC in dry cropland soils may be due to longer history of cultivation with straw return, which leads to more organic C input into soil and thus SOC enhancement (Zhang T T et al., 2010; Li et al., 2016). Han D R et al. (2018) also reported that large SOC increase in the agriculture lands of the North China Plain from 1980 to 2010 is due to successful desalinization and subsequent increases of $\mathrm{C}$ inputs, such as improved cultivation managements (i.e., fertilizer application and straw return). On the other hand, the relatively lower SOC in paddy soils may be due to salt washing, which could cause losses of soil C during saltleaching process (Jobbágy and Jackson, 2001). Interestingly, SOC density in reed soils $\left(4.68 \mathrm{~kg} \mathrm{C} \mathrm{m}^{-2}\right)$ is comparable with that in dry cropland soils in the middle-lower YRD, which may be due to lower decomposition rates of soil organic matter under the anaerobic condition in natural wetland $(\mathrm{Li}$ et al., 2014; Zhao et al., 2017, 2018).

The differences in SOC density among different land use types could be partly related to spatial heterogeneity in sedimentological and hydrological characters in this area (Fang et al., 2005). Furthermore, the development of cropping system in the middle-lower YRD was largely based on soil salinity, i.e., wheat-maize and cotton on low salinity soils and paddy on high salinity soils (Li et al., 2016), implying that there might be some differences in soil $\mathrm{C}$ density prior to land use in the YRD.

\section{Effects of land use and salinization on SIC}

Mean SIC density of dry cropland $\left(15.5 \mathrm{~kg} \mathrm{C} \mathrm{m}^{-2}\right)$ over $0-100 \mathrm{~cm}$ soil layer in the middle-lower YRD is close to that (16.9 $\mathrm{kg} \mathrm{C} \mathrm{m}^{-2}$ ) in the upper YRD (Guo et al., 2016), but much lower than that of Northwest China (e.g., 21.6-22.1 kg $\mathrm{C} \mathrm{m}^{-2}$ in the Loess Plateau (Chang et al., 2012; Zhang et al., 2015) and $42.0 \mathrm{~kg} \mathrm{C} \mathrm{m}^{-2}$ in the Yanqi Basin (Wang J P et al., 2015)). The large differences between the (semi-)arid regions and semi-humid areas may be attributable to the climatic conditions and associated hydrological cycles (Wang et al., 2018). For instance, relatively higher precipitation in the YRD could result in dissolution of soil carbonate, and subsequently the leaching of bicarbonate and $\mathrm{Ca}^{2+} / \mathrm{Mg}^{2+}$ down to deeper soil or groundwater (Shi et al., 2017). In addition, the lower levels of SOC density in the middle-lower YRD can cause less $\mathrm{CO}_{2}$ production, thus smaller $\mathrm{C}$ sources for carbonate precipitation, leading to lower levels of SIC density (Wang X J et al., 2015).

Effects of land use on SIC are complex because carbonate precipitation and dissolution may be affected by both biotic and abiotic processes (Monger and Gallegos, 2000). Our study shows a lower SIC density in paddy $\left(14.09 \mathrm{~kg} \mathrm{C} \mathrm{m}^{-2}\right)$ and reed $\left(15.02 \mathrm{~kg} \mathrm{C} \mathrm{m}^{-2}\right)$ soils than in maize-wheat soils (16.24 $\mathrm{kg} \mathrm{C} \mathrm{m}^{-2}$ ) in the middle-lower YRD. Anaerobic conditions in flooded or saturated soil often inhibit microbial activities, causing a lower decomposition rate of soil organic matter (Zhao et al., 2018), thus a smaller source of C, which 
is unfavorable for carbonate precipitation (Wang X $\mathrm{J}$ et al., 2015). Such impact may be greater in paddy soils because of the lower levels of SOC. On the other hand, periodic salt washing and draining in paddy soils can cause dissolution of soil carbonate and removal of bicarbonate and $\mathrm{Ca}^{2+} / \mathrm{Mg}^{2+}$, leading to lower SIC levels in the upper part of soil profile (Sartori et al., 2007; Tang et al., 2016). Our analyses show that water-soluble $\mathrm{Ca}^{2+}$ content was significantly higher in dry croplands than in paddy soils, especially below $20 \mathrm{~cm}$ soil depth (Table I). There was a significant positive correlation $(P<0.05)$ between SIC and water-soluble $\mathrm{Ca}^{2+}$ in the $0-100 \mathrm{~cm}$ layer of the dry cropland soils. Similar findings on the SIC-Ca ${ }^{2+}$ relationship was also reported for the maizewheat cropland soils of upper YRD (Guo et al., 2016). Apparently, land use and management have large influences on the formation and transformation of SIC in salt-affected lands.

Impacts of land use and salinization on the SIC-SOC relationship

Our analyses demonstrate that in dry cropland soil, SIC density has a significant positive correlation with SOC density in both the $0-20$ and $0-100 \mathrm{~cm}$ soil layers $(P<0.001)$ (Fig. 4). Similar findings of positive SIC-SOC relationship were reported for the Hebei Plain in China (Shi et al., 2017) and the Yanqi Basin of Northwest China (Wang X J et al., 2015). On the other hand, some studies showed a negative SIC-SOC relationship in the topsoil, including cropland in the Hebei Plain (Li et al., 2010) and non-cropland (grass, shrub, and forest lands) in the Loess Plateau (Zhang et al., 2015; Zhao et al., 2016; Han X Y et al., 2018).

Limited studies have reported a significant negative relationship between SIC and SOC in paddy soils, e.g., in the Hangzhou Bay (Du et al., 2012) and the Songnen Plain of East China (Tang et al., 2016). Despite the non-significant negative SIC-SOC relationship in the middle-lower YRD, higher SIC levels corresponded to lower SOC densities in paddy and reed soils, particularly in the $0-100 \mathrm{~cm}$ layer (Fig. 4).
Negative relationship between SIC and SOC stocks in paddy soils may be explained by the equilibrium of carbonate precipitation and dissolution:

$\mathrm{Ca}^{2+}+2 \mathrm{HCO}_{3}^{-} \leftrightharpoons \mathrm{CaCO}_{3}+\mathrm{CO}_{2}+\mathrm{H}_{2} \mathrm{O}$

In general, more $\mathrm{SOC}$ can produce more $\mathrm{CO}_{2}$ in the soil profile. The higher levels of $\mathrm{CO}_{2}$, together with water in paddy soils, would drive the above equation to the left, i.e., the dissolution of carbonate, leading to lower levels of SIC. In fact, Sartori et al. (2007) reported that decalcification might occur during the process of water percolation, and increasing SOM inputs could cause a reduction of SIC.

To better understand the effects of salinization on the SIC-SOC relationship, we compared the correlation in the dry cropland soils (maize-wheat and cotton) of middlelower YRD in this study with that in the upper YRD from Guo et al. (2016). While there was a significant positive correlation between SOC and SIC densities in both studies, the relationship differed largely (Fig. 5). The intercept was greater in the middle-lower YRD than in the upper YRD, which reflects the differences in SOC and SIC densities, i.e., significantly lower SOC in the middle-lower YRD (Tables II, IV, and V). The large SIC density in the middle-lower YRD may be due to the high levels of water soluble $\mathrm{Ca}^{2+} / \mathrm{Mg}^{2+}$ (Table IV). Previous studies have indicated that high levels of $\mathrm{Ca}^{2+}$ and $\mathrm{Mg}^{2+}$ in high $\mathrm{pH}$ soils can lead to enhanced carbonate precipitation (Bughio et al., 2016; Shi et al., 2017).

Implications of land use and management for soil C storage

There are numerous studies addressing the influences of land use and management on SOC dynamics, mainly focusing on topsoil (Fang et al., 2012; Chen et al., 2019). However, there is evidence of a great capacity for soil $\mathrm{C}$ storage in subsoil (Jobbágy and Jackson, 2000; Mikhailova and Post, 2006), and an increasing number of studies have shown that SOC/SIC stocks in the subsoil are highly variable among different land uses and managements (Chang et al., 2012; Zhang et al., 2015; Han X Y et al., 2018). Our analyses
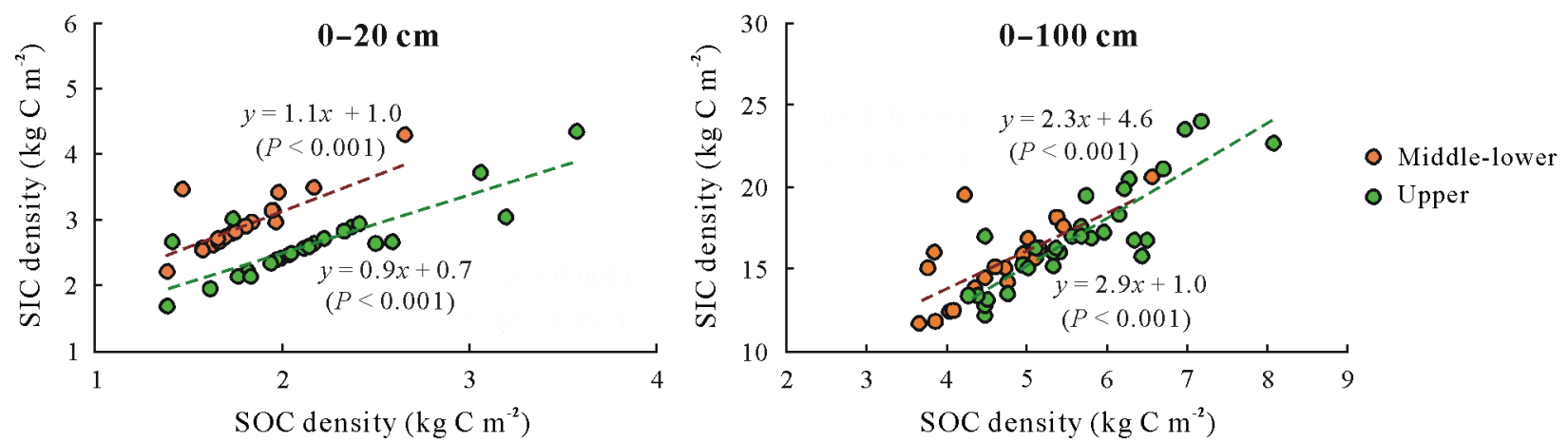

Fig. 5 Relationship between soil inorganic C (SIC) and organic C (SOC) densities in the 0-20 and 0-100 cm layers in dry cropland soils of the middle-lower (maize-wheat and cotton) and upper (maize-wheat) (Guo Y et al., 2016) Yellow River Delta, China. 
TABLE V

Soil organic C (SOC) and inorganic C (SIC) densities and estimated total soil C stock in the 0-100 cm soil layer in cropland of the middle-lower Yellow River Delta, China

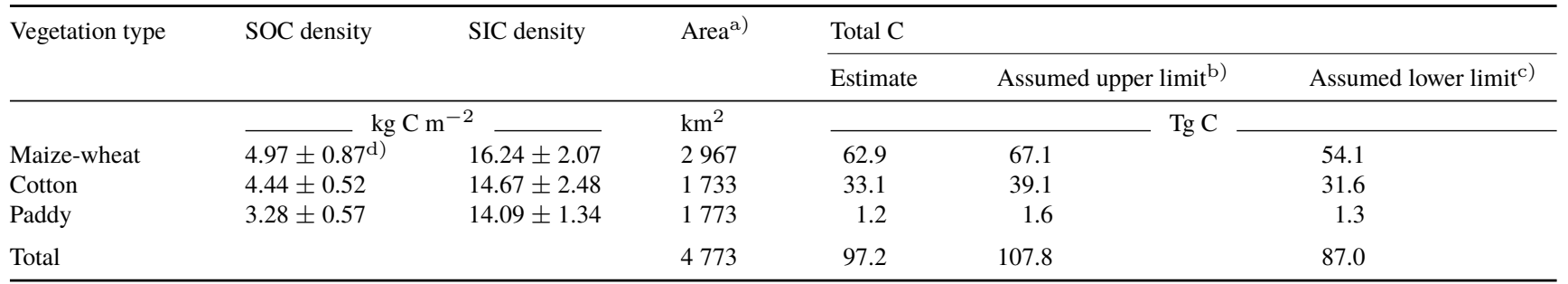

a) Sourced from the Shandong Statistical Yearbook (2016).

b) Calculated by assuming SOC and SIC densities of 5.73 and $16.89 \mathrm{~kg} \mathrm{C} \mathrm{m}^{-2}$, respectively.

c) Calculated by assuming SOC and SIC densities of 3.86 and $14.38 \mathrm{~kg} \mathrm{C} \mathrm{m}^{-2}$, respectively, which were averages from those of cotton and paddy soils.

d) Means \pm standard deviations ( $n=10$ for maize-wheat soils, 12 for cotton soils, 8 for paddy soils, and 4 for reed soils).

demonstrate that there are significant differences in both SOC and SIC densities below $20 \mathrm{~cm}$ among the different land use types, with significantly higher SOC and SIC densities and larger variations in the dry cropland soils (Table II).

The cropland area (including maize-wheat, cotton, and paddy) in the YRD is approximately $4.8 \times 10^{3} \mathrm{~km}^{2}$; thus, we estimated that SOC and SIC stocks were 22.6 and $74.6 \mathrm{Tg}$ $\mathrm{C}$, respectively (Table V). Given that low-to-middle salinity lands can have a maize-wheat rotation system, and lands with high salinity can only be suitable for cultivating cotton and rice in the YRD, any changes in land gradation would have impacts on soil $\mathrm{C}$ storage. Amelioration of saline-alkaline soil not only results in improvements of soil physical and chemical properties (Nan et al., 2016; Meng et al., 2019), but also leads to increased SOC and SIC densities (Lal, 2002; Amini et al., 2016). As shown in Table V, if soil salinization could be abated with soil quality improved as those in the upper YRD, soil C storage would be increased by $10 \%(10.6 \mathrm{Tg} \mathrm{C})$ in cropland of the YRD. However, if soil degradation occurs, with worsened salinization (as in cotton and paddy soils), soil $\mathrm{C}$ storage might be reduced by $10 \%$ (10.2 Tg C) in cropland of the YRD. Therefore, land management has impacts not only on agricultural production, but also on soil $\mathrm{C}$ storage.

\section{CONCLUSIONS}

This study reports the spatial distributions of SIC and SOC under various land use types in the middle-lower YRD. For the upper 100-cm soil depth, both SOC and SIC densities were significantly higher $(P<0.05)$ in dry cropland soils (maize-wheat and cotton) than in paddy soils. Compared with paddy soils, reed soils contained significantly higher $(P<$ $0.05)$ SOC and slightly higher SIC. Our analyses showed a significant positive SOC-SIC relationship in dry cropland soils, but a potentially negative relationship in paddy soils. On average, SOC and SIC densities were $15 \%$ and $4 \%$ lower in the middle-lower YRD than in the upper YRD for the maizewheat cropping system, due to the influences of cultivating history and soil salinization. This study demonstrates that soil salinization has adverse effects on soil C storage, and land use type can influence both SOC and SIC densities in the YRD.

\section{ACKNOWLEDGEMENTS}

This study was financially supported by the National Natural Science Foundation of China (Nos. 41877028 and 41205104). This work also contributes to the activities of N-Circle projects, a UK-China Virtual Joint Centre on Nitrogen, funded by the Newton Fund via Biotechnology and Biological Sciences Research Council (BBSRC) (No. BB/N013484/1).

\section{REFERENCES}

Amini S, Ghadiri H, Chen C R, Marschner P. 2016. Salt-affected soils, reclamation, carbon dynamics, and biochar: A review. $J$ Soil Sediment. 16: 939-953.

Batjes N H. 1996. Total carbon and nitrogen in the soils of the world. Eur J Soil Sci. 47: 151-163.

Bughio M A, Wang P L, Meng F Q, Qing C, Kuzyakov Y, Wang X J, Junejo S A. 2016. Neoformation of pedogenic carbonates by irrigation and fertilization and their contribution to carbon sequestration in soil. Geoderma. 262: 12-19.

Chang R Y, Fu B J, Liu G H, Wang S, Yao X L. 2012. The effects of afforestation on soil organic and inorganic carbon: A case study of the Loess Plateau of China. Catena. 95: 145-152.

Chen S C, Arrouays D, Angers D A, Martin M P, Walter C. 2019. Soil carbon stocks under different land uses and the applicability of the soil carbon saturation concept. Soil Tillage Res. 188: 53-58.

Cooperative Research Group on Chinese Soil Taxonomy. 2001. Chinese Soil Taxonomy. Science Press, Beijing.

Cui B S, Zhang Q J, Zhang K J, Liu X H, Zhang H G. 2011. Analyzing trophic transfer of heavy metals for food webs in the newly-formed wetlands of the Yellow River Delta, China. Environ Pollut. 159: 1297-1306.

Du C W, Zhou J M, Goyne W K. 2012. Organic and inorganic carbon in paddy soil as evaluated by mid-infrared photoacoustic spectroscopy. PLOS ONE. 7: e43368.

Eswaran H, Reich P E, Kimble J M, Beinroth F H, Padmanabhan E, Moncharoen P, Kimble J M. 2000. Global carbon stocks. In Lal R, Kimble J M, Eswaran H, Stewart B A (eds.) Global Climate Change and Pedogenic Carbonates. Lewis Publishers, Boca Raton. pp. 15-27. 
Eswaran H, Van den Berg E, Reich P. 1993. Organic carbon in soils of the world. Soil Sci Soc Am J. 57: 192-194.

Fang H L, Liu G H, Kearney M. 2005. Georelational analysis of soil type, soil salt content, landform, and land use in the Yellow River Delta, China. Environ Manag. 35: 72-83.

Fang X, Xue Z J, Li B C, An S S. 2012. Soil organic carbon distribution in relation to land use and its storage in a small watershed of the Loess Plateau, China. Catena. 88: 6-13.

Gao Y, Tian J, Pang Y, Liu J B. 2017. Soil inorganic carbon sequestration following afforestation is probably induced by pedogenic carbonate formation in Northwest China. Front Plant Sci. 8: 1282.

Guo Y, Wang X J, Li X L, Wang J P, Xu M G, Li D W. 2016. Dynamics of soil organic and inorganic carbon in the cropland of upper Yellow River Delta, China. Sci Rep. 6: 36105.

Han D R, Wiesmeier M, Conant R T, Kühnel A, Sun Z G, Kögel-Knabner I, Hou R X, Cong P F, Liang R B, Ouyang Z. 2018. Large soil organic carbon increase due to improved agronomic management in the North China Plain from 1980s to 2010s. Global Change Biol. 24: 987-1000.

Han X Y, Gao G Y, Chang R Y, Li Z S, Ma Y, Wang S, Wang C, Lü Y L, Fu B J. 2018. Changes in soil organic and inorganic carbon stocks in deep profiles following cropland abandonment along a precipitation gradient across the Loess Plateau of China. Agric Ecosyst Environ. 258: 1-13.

Jobbágy E G, Jackson R B. 2000. The vertical distribution of soil organic carbon and its relation to climate and vegetation. Ecol Appl. 10: 423436.

Jobbágy E G, Jackson R B. 2001. The distribution of soil nutrients with depth: Global patterns and the imprint of plants. Biogeochemistry. $\mathbf{5 3}$ 51-77.

Lal R. 2002. Soil carbon sequestration in China through agricultura intensification, and restoration of degraded and desertified ecosystems. Land Degrad Dev. 13: 469-478.

Lal R. 2004. Soil carbon sequestration impacts on global climate change and food security. Science. 304: 1623-1627.

Li G T, Zhang C L, Zhang H J. 2010. Soil inorganic carbon pool changed in long-term fertilization experiments in North China Plain. In IUSS (ed.) Proceedings of the 19th World Congress of Soil Science, Soil Solutions for a Changing World. IUSS, Brisbane. pp. 220-223.

Li Y, Zhang H B, Chen X B, Tu C, Luo Y M. 2014. Gradient distributions of nitrogen and organic carbon in the soils from inland to tidal flat in the Yellow River Delta. Geochimica (in Chinese). 43: 338-345.

Li Y, Zhang H B, Li Q B, Zhou Q, Chen X B, Tu C, Luo Y M, Christie P, Hu X F, Li L Z. 2016. Characteristics of residual organochlorine pesticides in soils under different land-use types on a coastal plain of the Yellow River Delta. Environ Geochem Health. 38: 535-547.

Meng F Q, Lal R, Kuang X, Ding G W, Wu W L. 2014. Soil organic carbon dynamics within density and particle-size fractions of Aquic Cambisols under different land use in northern China. Geoderma Reg. 1: 1-9.

Meng Q F, Ma X F, Zhang J, Yu Z T. 2019. The long-term effects of cattle manure application to agricultural soils as a natural-based solution to combat salinization. Catena. 175: 193-202.

Mikhailova E A, Post C J. 2006. Effects of land use on soil inorganic carbon stocks in the Russian Chernozem. J Environ Qual. 35: 1384-1388.

Monger H C, Gallegos R A. 2000. Biotic and abiotic processes and rates of pedogenic carbonate accumulation in the southwestern United Statesrelationship to atmospheric $\mathrm{CO}_{2}$ sequestration. In Lal R, Kimble J M, Eswaran H, Stewart B A (eds.) Global Climate Change and Pedogenic Carbonates. CRC Press, Boca Raton. pp. 273-289.

Nan J K, Chen X M, Chen C, Lashari M S, Deng J Q, Du Z J. 2016. Impact of flue gas desulfurization gypsum and lignite humic acid application on soil organic matter and physical properties of a saline-sodic farmland soil in Eastern China. J Soil Sediment. 16: 2175-2185.

Rosenzweig C, Hillel D. 2000. Soils and global climate change: Challenges and opportunities. Soil Sci. 165: 47-56.

Sartori F, Lal R, Ebinger M H, Eaton J A. 2007. Changes in soil carbon and nutrient pools along a chronosequence of poplar plantations in the Columbia Plateau, Oregon, USA. Agric Ecosyst Environ. 122: 325-339.

Schlesinger W H. 1999. Carbon sequestration in soils. Science. 284: 2095
Shi H J, Wang X J, Zhao Y J, Xu M G, Li D W, Guo Y. 2017. Relationship between soil inorganic carbon and organic carbon in the wheat-maize cropland of the North China Plain. Plant Soil. 418: 423-436.

Su Y Z, Wang X F, Yang R, Lee J. 2010. Effects of sandy desertified land rehabilitation on soil carbon sequestration and aggregation in an arid region in China. J Environ Manag. 91: 2109-2116.

Tan W F, Zhang R, Cao H, Huang C Q, Yang Q K, Wang M K, Koopal L K. 2014. Soil inorganic carbon stock under different soil types and land uses on the Loess Plateau Region of China. Catena. 121: 22-30.

Tang J, Liang S, Li Z Y, Zhang H, Lou Y, Wang J J. 2016. Effect of freeze-thaw cycles on carbon stocks of saline-alkali paddy soil. Arch Agron Soil Sci. 62: 1640-1653.

Wang J P, Wang X J, Zhang J, Zhao C Y. 2015. Soil organic and inorganic carbon and stable carbon isotopes in the Yanqi Basin of northwestern China. Eur J Soil Sci. 66: 95-103.

Wang X J, Wang J P, Xu M G, Zhang W J, Fan T L, Zhang J. 2015 Carbon accumulation in arid croplands of Northwest China: Pedogenic carbonate exceeding organic carbon. Sci Rep. 5: 11439.

Wang X J, Xu M G, Wang J P, Zhang W J, Yang X Y, Huang S M, Liu H. 2014. Fertilization enhancing carbon sequestration as carbonate in arid cropland: Assessments of long-term experiments in northern China. Plant Soil. 380: 89-100.

Wang X J, Yu Z T, Wang J P, Zhang J. 2018. Carbon Cycle in the Changing Arid Land of China: Yanqi Basin and Bosten Lake. Springer, Singapore.

Wang Z R, Zhao G X, Gao M X, Chang C Y. 2017. Spatial variability of soil salinity in coastal saline soil at different scales in the Yellow River Delta, China. Environ Monit Assess. 189: 80.

Wu H B, Guo Z T, Gao Q, Peng C H. 2009. Distribution of soil inorganic carbon storage and its changes due to agricultural land use activity in China. Agric Ecosyst Environ. 129: 413-421.

Wu H B, Guo Z T, Peng C H. 2003. Distribution and storage of soil organic carbon in China. Global Biogeochem Cycl. 17: 1048.

Yu J B, Li Y Z, Han G X, Zhou D, Fu Y Q, Guan B, Wang G M, Ning K, Wu H F, Wang J H. 2014. The spatial distribution characteristics of soil salinity in coastal zone of the Yellow River Delta. Environ Earth Sci. 72: 589-599.

Yu J B, Zhan C, Li Y Z, Zhou D, Fu Y Q, Chu X J, Xing Q H, Han G X, Wang G M, Guan B. 2016. Distribution of carbon, nitrogen and phosphorus in coastal wetland soil related land use in the modern Yellow River Delta. Sci Rep. 6: 37940.

Zeng J, Guo T W, Bao G X, Wang Z, Sun J H. 2008. Effections of soil organic carbon and soil inorganic carbon under long-term fertilization. Soil Fertil Sci China (in Chinese). 2008: 11-14.

Zhang F, Wang X J, Guo T W, Zhang P L, Wang J P. 2015. Soil organic and inorganic carbon in the Loess profiles of Lanzhou area: Implications of deep soils. Catena. 126: 68-74.

Zhang N, He X D, Gao Y B, Li Y H, Wang H T, Ma D, Zhang R, Yang S. 2010. Pedogenic carbonate and soil dehydrogenase activity in response to soil organic matter in Artemisia ordosica community. Pedosphere. 20: $229-235$.

Zhang T T, Zeng S L, Gao Y, Ouyang Z T, Li B, Fang C M, Zhao B. 2011. Assessing impact of land uses on land salinization in the Yellow River Delta, China using an integrated and spatial statistical model. Land Use Policy. 28: 857-866.

Zhang W J, Wang X J, Xu M G, Huang S M, Liu H, Peng C. 2010. Soil organic carbon dynamics under long-term fertilizations in arable land of northern China. Biogeosciences. 7: 409-425.

Zhao Q Q, Bai J H, Lu Q Q, Zhang G L. 2017. Effects of salinity on dynamics of soil carbon in degraded coastal wetlands: Implications on wetland restoration. Phys Chem Earth, Parts A/B/C. 97: 12-18.

Zhao Q Q, Bai J H, Zhang G L, Jia J J, Wang W, Wang X. 2018. Effects of water and salinity regulation measures on soil carbon sequestration in coastal wetlands of the Yellow River Delta. Geoderma. 319: 212-229.

Zhao W, Zhang R, Huang C Q, Wang B Q, Cao H, Koopal L K, Tan W F. 2016. Effect of different vegetation cover on the vertical distribution of soil organic and inorganic carbon in the Zhifanggou Watershed on the Loess Plateau. Catena. 139: 191-198. 